\title{
Middle and Late Holocene hunter-gatherers in East Central Europe: changing paradigms of the 'non-Neolithic' way of life
}

\author{
Marek Nowak \\ Institute of Archaeology, Jagiellonian University, Kraków, Poland \\ mniauj@interia.pl
}

\begin{abstract}
According to traditional views, the main reason for 'demesolithisation' in East Central Europe was the spread of the Neolithic oecumene, particularly from c. 4000 BC. Simultaneously, the disintegrated Late Mesolithic world gradually underwent typological unification, and finally reached the stage that is sometimes described as pre-Neolithic. However, we definitely have to bear in mind that as a matter of fact we deal only with the 'history' of archaeological artefacts that are treated as typical attributes of hunter-gatherers. The analyses of chronological, technological, settlement, economic, and social data referring to foragers of East Central Europe demonstrate that the quantitative decrease and changes of their archaeological attributes in the fifth, fourth, and third millennia were not connected with a profound reorientation of their spatial and ideological existence. It was rather a continuation of previous patterns, even though territories settled by farming societies were steadily growing in size. The final disappearance of Central European hunter-gatherers - but only in a strictly typological dimension - took place in the Late Neolithic and Early Bronze Age.
\end{abstract}

IZVLEČEK - Glede na tradicionalne poglede je bil glavni razlog 'de-mezolitizacije' v vzhodni srednji Evropi širitev neolitske ekumene, predvsem od c. 4000 BC dalje. Istočasno je mlajši mezolitski svet postopoma doživel tipološko zedinjenje in končno dosegel stopnjo, ki je včasih opisana kot pred-neolitska. Vendar moramo jasno vedeti, da se dejansko ukvarjamo le z zgodovino arheoloških artefaktov, ki jih obravnavamo kot tipične atribute lovcev in nabiralcev. Analize kronoloških, tehnoloških, poselitvenih, ekonomskih in socialnih podatkov, ki se nanašajo na nabiralce vzhodne srednje Evrope dokazujejo, da kvantitativni upad in spremembe njihovih arheoloških atributov v petem, četrtem in tretjem tisočletju niso bili povezani s temeljito, novo usmeritvijo prostorske in ideološke eksistence. Šlo je večinoma za nadaljevanje prejšnjih vzorcev, čeprav so se območja, ki so jih poselili kmetovalci, stalno povečevala. Končno izginotje srednjeevropskih lovcev in nabiralcev - vendar v striktno tipološki razsežnosti - se je dogodilo v mlajšem neolitiku in v začetku bronaste dobe.

KEY WORDS - East Central Europe; late hunter-gatherers; Late/Final Mesolithic; para-Neolithic

\section{Introduction}

In reference to western regions of Central Europe, the Early Atlantic part of Mesolithic development is usually described as its late, final or terminal phase (Arts 1989; Cupillard, Perrenoud-Cupillard 2003; De Roever 2004; Gronenborn 1999; Jochim 1998; Kind 1997; Louve-Kooijmans 2003; Raemakers 1999; Taute 1974). It seems that indeed this was the last stage of the existence of foraging populations there, as opposed to eastern regions of Central Europe, as well as southern Scandinavia. In the latter, for instance, the Late Mesolithic survived until the turn of the fifth and fourth millennia BC (Larsson 1990). The chronology of the final disappearance of the Mesolithic in the former regions (Fig. 1) has so far remained controversial. According to some views, this could have taken place as late as the third millennium BC (Bagniewski 1998; 1999; 2001a; Galinski 1991; 2002; Kobusiewicz 1999; Kozłowski 1989). Regardless of the exact dates of its disappearance, the condition of late hunter-gatherers in this 
territory is often described as 'demesolithisation', disintegration, or even as regression, decline, and degeneration (Galinski 1991; Kozłowski 1989).

On the other hand, when late hunter-gatherers, as living within the described territories, are considered, it is often ignored that several specific communities which cannot be strictly classified either as Neolithic or Mesolithic in accordance with classic archaeological categorisation did inhabit vast regions of Eastern and East Central Europe in the Early and Middle Holocene. The economy of these communities was based mainly on hunting and gathering, but in some areas there was some limited familiarity with agriculture (Dolukhanov et al. 2005; Guminski 1998; 2003a; Gumiński, Michniewicz 2003; Kalecyc 2001). For archaeologists, perhaps the most characteristic feature of the material culture of these communities is the widespread production and use of pottery. These vessels have a distinctive technology, morphology and decoration - quite different from the strictly Neolithic ceramics made by farming communities (Kempisty 1983). The flint industries in question also have their own unique features, yet tend to resemble those of the typical Mesolithic (Kempisty, Sulgostowska 1991; Kempisty, Więckowska 1983; Schild 1989; Sulgostowska 1998). Such communities appeared along the southern borders of Eastern Europe in the early eighth millennium BC at the very latest, and subsequently spread over the territory of Eastern and East Central Europe (Antanaitis 1999; Dolukhanov et al. 2005; Józwiak 2003; Rimantiene 1992; 1994; Timofieev 1998). They remained in the region for several millennia and were only eclipsed in the Bronze Age by the transition to the new type of material culture, and to to greater

Fig. 1. Territory and sites discussed in the text.

1 - Augustów-Wójtowskie Wtóki; 2 Baraki Stare 13; 3 -Bartków 7; 4 Bierzwnik 19; 5 - Bobrowice; 6 Brodno E; Brodno 3; 7 - Bukówna 5; 8 - Buszów; 9 - Chobienice 8; 10 - Chrapów 17; 11 - Chwalim 1; 12 - Czeladź Wielka I; Czeladź Wielka II; 13 - Dabki 9; 14 - Dąbrowa Krepnica 5; 15 - Dobra 53, I/83; Dobra 53, III/83; Dobra 53, IV/84; 16 - Dudka; 17 - Dzierżno 3; 18 Glanów 3; 19 - Gorzupia Dolna 2; 20 - Gościm 23; 21 - Grądy Woniecko; 22 - Grudziąd-Mniszek; 23 - Grzepnica 7, sk. E; Grzepnica 7, I/84; 24 - Gudowo 3; 25 - Gwoździec; 26 -Jaglisko 1; 27 -Jaroszówka-Kolonia 10; 28 - Jastrzębia Góra 4; 29 -Jastrzębnik 5; 30 - Kalisz Pomorski 33; 31 - Komornica I; 32 - Korzecznik 6/7; 33 - KoszalinDzierżęcino 7; 34 - Krzekotówek 8; 35 - Kuców; 36 - Lubiatów II; Lu-

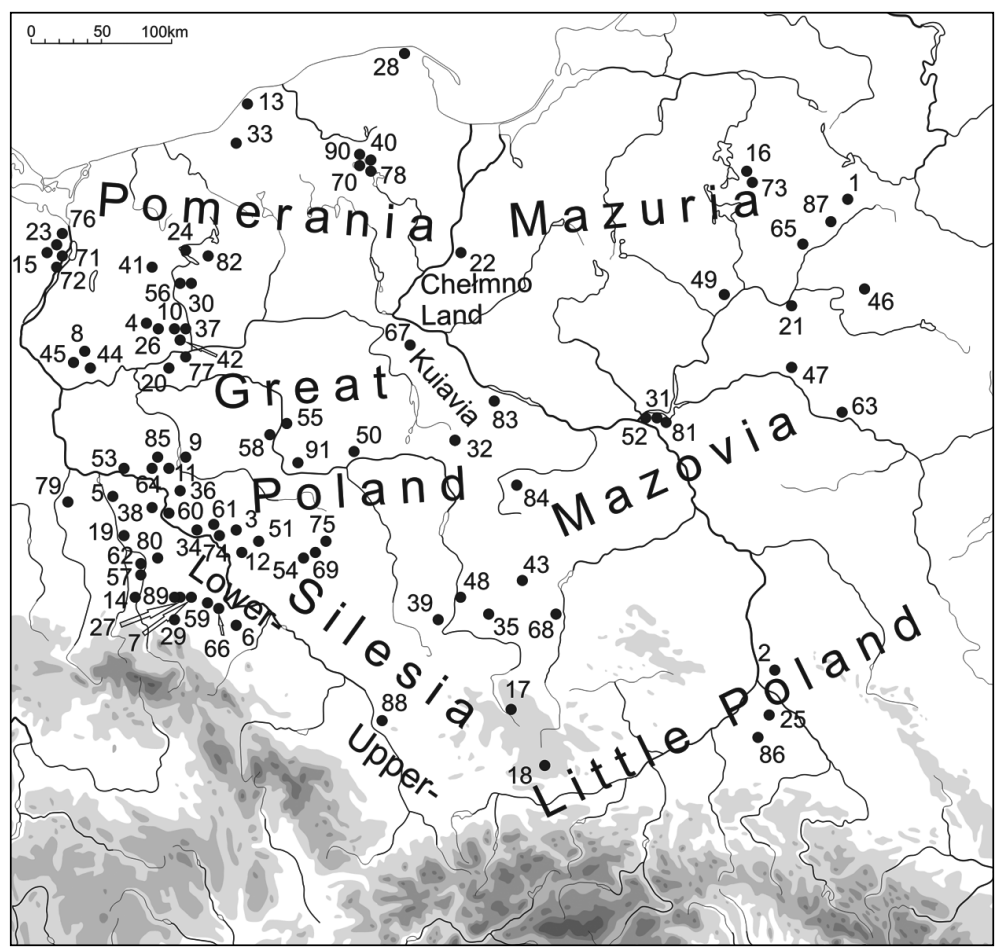
biatów III; 37 - Leczyn 12; Lęczyn 13; Lęzyn 22; Lęczyn 23; tęczyn 25; 38 - tugi E; 39 - Lykowe; 40 Męcikat 6; Męcikat 7a; Męcikat 7b; Męcikat 11; 41 - Miatka 4; 42 - Mierzęcin 65; 43 - Mokracz; 44 - Mosina 10; 45 - Mostno 15; Mostno 16; 46 - Nowodworce 1; 47 - Nur-Kolonia 1; 48 - Osjaków; 49 - Pianki I; Pianki II; 50 - Pietrzyków „g”; 51 - Pobiel 9; Pobiel 10; 52 - Poddębe I; 53 - Pomorsko 1; 54 - Potasznia 1; 55 - Poznań-Starotęka 1; 56 - Prostynia 16; 57 - Pstraże; 58 - Puszczykowo 21; 59 - Rzeszotary 17; 60 - Siedlisko 16; 61 - Siedlnica 6; 62 - Sieraków 4; 63 - Stochy Annopolskie; 64 - Smolno Wielkie 1; Smolno Wielkie 2; 65 - Sośnia I; 66 - Spalona 12, I, Ia/85; 67 - Stara Wieś 9a; 68 - Stobnica-Trzymorgi; 69 - Sutów 1; 70 - Swornegacie 3; Swornegacie 6; 71 - Szczecin-Jezierzyce 19; 72 - Szczecin-Śmierdnica; 73 - Szczepanki; 74 - Świerczów; 75 - Świętoszyn 1; Świętoszyn II; Świętoszyn III; 76 - Tanowo 2, I/82 (sk. 2); Tanowo 3; 77 - Trzebicz Mtyn 1; Trzebicz Mtyn 2; 78 - Turowiec 1; Turowiec 3; 79 - Wegliny 12; 80 - Wiechlice I; 81 - Wieliszew 12 (XIV/1960); Wieliszew I, sk. II; Wieliszew III, sk. XVI; Wieliszew VIB, wykop XVIIc; Wieliszew VIII, wykop IX; Wieliszew XIII/1960/62; Wieliszew XII-XI; 82 Wierzchowo 1; Wierzchowo 2; 83 - Wistka Szlachecka I/1963; Wistka Szlachecka V/1960; Wistka Szlachecka VI/19660; 84 - Witów 1; 85 - Wojnowo 1; 86 - Wola Raniżowska; 87 - Woźna Wieś 1; Woźna Wieś 2; 88 - Zakrzów 6; 89 - Zamienice 10; 90 - Zbrzyca 2; Zbrzyca 5; 91 - Zwola 2. 
significance of agricultural economy. It was mainly the use of pottery by these hunter-gatherers that undermined the classic distinction between the Mesolithic and Neolithic, and spawned a series of adapted terms such as the para-Neolithic, proto-Neolithic, subNeolithic, Forest Neolithic, Comb-Pitted Pottery Complex, and the Ceramic Mesolithic, Hyperborean Horizon, not to mention less popular ones (Gronenborn 2003; Janik 1998; Kobusiewicz 2001; Werbart 1998). It should also be remembered that East European archaeologists usually consider this phenomenon as simply Neolithic (e.g. Čarniauski 2004; Rimantiene 1998), which complicates the matter even further. In this paper I am going to use either the neutral term 'pottery-using hunter-gatherers', or the word 'para-Neolithic', introduced by the late Elżbieta Kempisty over twenty years ago (Kempisty 1982).

It is a very common approach in the archaeological literature to make a clear distinction between Mesolithic and para-Neolithic populations. For example, in Polish and Belarusian territories we have, on the one hand, Mesolithic groupings, and on the other hand, the Neman Culture and the so-called Linin Horizon, both belonging to the para-Neolithic or, if we use 'eastern' terminology, the Neolithic. The difference lies in the relation between these terms. In Belarus, as typically in East European approaches, the relation is linear; that is, the Mesolithic is viewed as replaced by consecutive developmental stages of the para-Neolithic (or, in East European terminology, the Neolithic) (Čarniauski 2004). What is stressed in some approaches in reference to Polish territories, however, is the rather long co-existence of the Mesolithic and the para-Neolithic (Józwiak 2003).

Terminological problems arise also in connection with those 'Polish' sites where Ertebølle-type pottery was found, which indeed bears some resemblance to para-Neolithic pottery. Flint inventories from these sites are typically Mesolithic, of the post-Maglemosian tradition, with either no or only token occurrences of features that are characteristic of Ertebølle flint industries (Ilkiewicz 1989; Kabacinski 2001). Again, the picture is blurred, as at some sites (e.g. Dabki) the bones of domesticated animals were found (Ilikiewicz 1989). The phenomenon then, in my opinion, is actually of the same dimension as the paraNeolithic. Therefore, whenever applying the term, I am going to refer to the above-mentioned sites containing Ertebølle pottery.

In my paper I will argue that neither i) negative connotations of the Late Mesolithic in East Central Eu- rope, nor ii) the distinction between the Mesolithic and para-Neolithic in this territory can be justified. Both stem from a traditional methodology which: i) considers the archaeological past as a roughly linear set of units and stages, and ii) takes the appearance of elements of the so-called Neolithic package at their face value only (which in a measure is connected with the general conviction that a hunting-gathering mode of existence is inferior to agriculture, and that even sporadic and scarce Neolithic attributes brought about significant changes in the economic, social and ideological spheres).

\section{Chronology of late hunter-gatherers}

First of all, we should address chronology issues and remember that radiometric data referring to, generally speaking, non-Neolithic phenomena in East Central Europe (Fig. 1) suggest a very long history of hunter-gatherers. If we considered all the ${ }^{14} \mathrm{C}$ dates available, later than 6000 BP (Figs. 2a, 2b), it would turn out that these phenomena came to an end only in the Early Bronze Age. What is more important, at least in theory, is that there would be no significant difference between radiocarbon dates from pottery and non-pottery contexts, or in other words, from more or less para-Neolithic and Mesolithic contexts (Fig. 3). The real value of these dates has been the subject of many debates, regretfully surrounding only the question of the Late Mesolithic in Poland (Bagniewski 1979; 1982; 1987; 1998; Czerniak 1994.9-10; Galiński 1991; Kabaciński 1992; Kobusiewicz 1999; Kozłowski 1989; Kukawka 1997. 82, 129-135; Schild 1998). One major problem is the apparent homogeneity of many sites containing Mesolithic and para-Neolithic materials, caused by geological and geomorphological factors that at most sites considerably interfere with the sequence of deposition of natural and anthropogenic sediments, as well as archaeological artefacts (Schild 1989). Thus, probably a large proportion or even the majority of the quoted radiocarbon dates come from mixed contexts, embracing both Mesolithic and para-Neolithic remains. In such cases we are unable to determine whether samples used for ${ }^{14} \mathrm{C}$ dating are connected with a Mesolithic or para-Neolithic milieu. Yet if we assume, as I will strive to demonstrate, that in view of cultural development the distinction between the Mesolithic and the para-Neolithic is not paramount, the perspective is slightly altered. Since the similarities in the material culture and the modes of settlement and economy are significant, as indicated below, then the dates, all in all, refer to phenomena relating to hunter-gatherers, and so existing, culturally, 
Fig. 2a. Radiocarbon dates later than 6000 BP from Poland, obtained outside of the Neolithic context; part 1.

Ba - Bartków 7 (Bagniewski 1979.76; 1982.83), Br Brodno E (Bagniewski 1991. 12), Chw - Chwalim 1 (Kobusiewicz, Kabaciński 1993), Db - Dąbki 9 (Ilkiewicz 1989. 18-21, Figs. 4, 5; Pazdur 1991), DK - Dąbrowa Krepnica 5 (Bagniewski 1982. 107), Du - Dudka (Gumiński, Fiedorczuk 1988.116-7; Gumiński 1999), Gl - Glanów 3 (Pazdur et al. 2004. 815), GM - Grudziadz-Mniszek (Bokiniec, Marciniak 1987; Kanwiszer, Trzeciak 1991.119), KP - Kalisz Pomorski 33 (Bagniewski 1996. 137), Ko - Korzecznik 6/7 (Olszewski 1987.53), Le Eeczyn 22 (Bagniewski 1999.133-4), Ly - Eykowe (Cyrek 1990; Kanwiszer, Trzeciak 1991.119-20), M6 - Męcikat 6 (Bagniewski 1987.114), M11 - Męcikat 11 (Bagniewski 1987.114), Mo - Mokracz (Niesiołowska-Śreniowska 1990a.309; 1998.69-73), No - Nowodworce 1 (Cyrek et al. 1985. 12-3; Nowak 1980.18-19; Kanwiszer, Trzeciak 1991. 115), Os - Osjaków (Kanwiszer, Trzeciak 1991.120121), Po - Pobiel 10 (Bagniewski 1990), Pr - Prostynia 16 (Bagniewski 1996.

137), Si - Siedlnica 6 (Bagniewski 1979; 1987.115), So - Sośnia I (Kempisty, Więckowska 1983.13, 81), SW - Stara Wieś 9a (Pazdur et al. 1994.263), Sw6 - Swornegacie 6 (Bagniewski 1987.114), Tn - Tanowo 3 (Galiński 2005. 87), Tu1 - Turowiec 1 (Bagniewski 1987.114), Tu3 - Turowiec 3 (Bagniewski 1987. 114), WW - Woźna Wiés 1 (Kempisty, Sulgostowska 1991.16, 84; Pazdur et al. 1994.260-261), Zb - Zbrzyca 5 (Bagniewski 1987.114).

outside the Neolithic proper. Summing up, despite the aforesaid difficulties in demarcating compact archaeological complexes on foraging sites, I would like to argue that lands outside the densely settled early agricultural enclaves were occupied by populations of hunter-gatherers until at least the end of the third millennium $\mathrm{BC}$, and possibly even longer; in other words, farmers lived alongside hunter-gatherers for at least 3500 years (see also Kośko, Szmyt 2004; Czebreszuk 2004). Cartographic analyses show that these Late Mesolithic settlements concentrated mainly in lowland areas, including the Pomeranian and Mazurian Lake Districts, some areas of northeastern Mazovia, Great Poland, Lower Silesia and central Poland (Fig. 1) (Nowak 2001.586).

Material culture, settlements and the economy of late hunter-gatherers

Beginning from the first half of the seventh millennium BC, the tool inventory of the European Mesolithic underwent typological and technological transformations which consisted in the ongoing standardisation of flint industries. With time, the process 




Fig. 2b. Radiocarbon dates later than 6000 BP from Poland, obtained outside of the Neolithic context; part 2. Site captions as in Figure $2 a$. standardised industries are quite similar to Early Neolithic ones, both in the Mediterranean zone and in Central Europe. Therefore he labeled them as pre-Neolithic. Although it remains an open question how to interpret this term, particularly in reference to the Neolithisation processes, the main value of the notion lies in the emphasis on the difference between 'classical' and later Mesolithic flint industries. Therefore, the traditional term 'Mesolithic', in the case of the most standardised industries, actually may not be appropriate at all, as suggested by some authors (Galiński 1994; Kozłowski 1989).

In East Central Europe these typological transformations are considered to be an indication of the aforementioned negative processes, which are generally called 'demesolithisation'. I am convinced this attitude should be challenged for at least two reasons. Firstly, there are no practical premises for such typological standardizations as degeneration or disintegration. It is possible that the situation was quite the reverse. A highly unified industry was actually the final product of a developmental trajectory aimed at was reinforced, and it either obliterated or diminished the hitherto typological diversity of Mesolithic inventories. Common attributes of this convergence process are mainly trapezes and truncations made of regular blade blanks, as well as end-scrapers and side-scrapers (Figs. 4, 5). The increasing frequency of the chipped technology aimed at receiving relatively long and regular blade blanks, called usually Montbani blades, is also typical of this process ( $\mathrm{Ga}$ linski 2002.69-72; Gronenborn 1999.126, 137; Kobusiewicz 1999.92; Kozłowski 1987; 1989; Was 2005; Wieckowska 1985.102). According to S. K. Kozłowski (1987; 1989.115-117; 2001), such highly the most efficient use of the chipped industry in a hunting-gathering economy in temperate and boreal zones. It was simply the most optimal stage of such development. An interpretation of this kind was proposed, for example, by Fischer (1989). Secondly, the unification was not as complete and widespread as many authors have suggested. The analysis of the typological situation within supposedly late huntergatherer lithic assemblages in Poland proves that we encounter many regional differences and variations. In reference to Figure 6, we should emphasize that the most numerous group, $3 \mathrm{c}$, has a moderate number of attributes of late chronology, whereas sites 
belonging to groups 1 and 2 (with the highest rate of late chronology features) are not so frequent. Besides, there are sites with either a very small number of late chronology features or none at all.

If we look at East Central Europe between roughly 6000 and 2000 BC (Galinski 2002; Kobusiewicz 1999; Kozłowski 1989; Koztowski, Kozłowski 1980), we will certainly perceive the decreasing number of sites and the shrinking territorial span of huntergatherer settlement (while keeping in mind that general maps, which show only basic spatial arrangements, may be misleading). Certainly, the main reason was the spread of the Neolithic oecumene, particularly from circa 4000 BC onwards (Fig. 7). However, we have to remember that we are dealing only with the 'history' of archaeological artefacts that are treated as typical attributes of hunter-gatherers. Their gradual disappearance, with concomitant unification and growing congruency with features of Neolithic farmers, does not necessary reflect the same story of the people who witnessed (either consciously or unconsciously) these material transformations. I think that a substantial part of the huntergatherer groups underwent Neolithisation in the fourth millennium BC: their material attributes were replaced by new ones, but the genetic pool of the population remained essentially the same. These new attributes belong to Neolithic units, first of all to the Funnel Beaker Culture (TRB). A good example of this process is the site of Tanowo, where we have an inventory of an absolutely rudimentary, perhaps transitional, character, judging from the TRB point of view (Galinski 2005). As a matter of fact, this inventory comprises Mesolithic, and paraNeolithic, as well as early TRB elements. The genetic process of the TRB, observed here, is very similar to the one in the Lower Elbe area, southern Scandinavia and the Netherlands. It has to be underlined that the foregoing scenarios are in no way sufficient as regards the origin of the entire Funnel Beaker Culture in East Central Europe. Surely, both Mesolithic and earlier Neolithic populations contributed to this phenomenon, but their share varied in different TRB territories. For instance, in southern groups of the TRB, the share of the Mesolithic background was negligible.

Despite the considerable expansion of the TRB and other Middle Neolithic cultures, they never encompassed all the territory of Poland, bypassing many areas where, in traditional terms, communities of Mesolithic and para-Neolithic hunter-gatherers existed alongside neighbouring farming groups in the
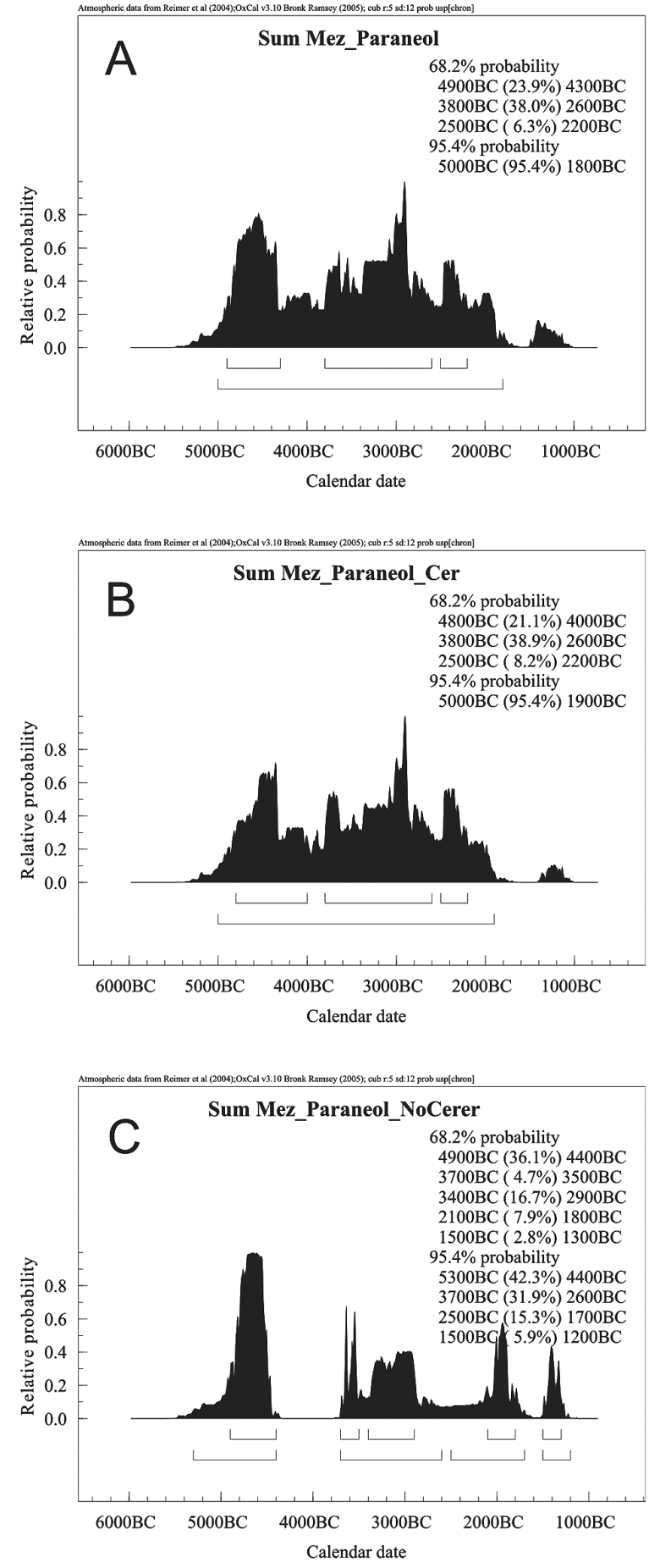

Fig. 3. Simple sums of probability of radiocarbon dates later than $6000 \mathrm{BP}$, from: $i$ ) all non-Neolithic sites (A), ii) non-Neolithic sites with pottery (B), iii) non-Neolithic sites without pottery (C).

fourth and third millennium BC (Fig. 7). Most of these late hunter-gatherer groups appear to have both made and used ceramics. This is particularly interesting, because their ceramic technology appears to have been inherited from East European para-Neolithic pottery traditions rather than adopted from the expanding Neolithic groups. This distinctive pot- 




Fig. 4. Selection of flint tools from the site of Dabrowa Krepnica 5. An example of the standardized flint industry of late hunter-gatherers (after Bagniewski 1982.94, Fig. 32). Trapezes: 1-34, blade truncations: 35-43, end-scrapers: 44-50.

tery is mainly concentrated in the north-eastern areas of Poland, but has been found in many other areas.

However, there is also specific type of ceramics used by late hunter-gatherers that bears some resemblance to the pottery made by the Neolithic farming communities who inhabited the eastern regions of Central Europe. Kempisty $(1972 ; 1973 ; 1983)$ defined this pottery as 'Linin Type', although more recently Józwiak (2003) included it in the Neman Culture as an 'unusual' element which forms the 'Linin horizon' within this culture. These ceramic traditions persisted for a considerably long period, from the second half of the fourth millennium $\mathrm{BC}$ to the early second millennium $\mathrm{BC}$, and included the adoption of several forms similar to those of subsequent Neolithic archaeological units. As a result of this borrowing and blending of pottery traditions, we can observe ceramics whose form is reminiscent of i) the TRB; ii) the Globular Amphora Culture; iii) the Corded Ware Culture; iv) the early Bronze Iwno Culture, with elements of the Bell Beaker Culture (these styles are designated, respectively, as Linin horizon A, B, C, and D according to Kempisty).
On the whole, distributions of para-Neolithic pottery proper and Linin style pottery are commonly interpreted as a reflection of the westward expansion of pottery-using East European hunter-gatherer communities into ecologically similar enclaves, and the ceramics have been argued to represent mainly part of the Neman and Zedmar Cultures (Guminski 2001; 2003b; Józwiak 2003; Kempisty 1983). Nonetheless, it should be noted such an image is quite hard to grasp when other archaeological evidence, and not exclusively pottery, is considered. I think it should be emphasised that there is a clear continuity in the flint industries preceding and following the adoption of pottery (trapezes, blade truncations, side-scrapers), which only sometimes were supplemented with 'para-Neolithic', eastern elements (points, retouched inserts, stone axes, bi-facial flat retouches, lamellar retouches) (Kempisty, Sulgostowska 1991; Kempisty, Więckowska 1983; Kobusiewicz 1999). Consequently, the distinction between the Late/Final Mesolithic and para-Neolithic episodes, from the 'flint perspective', is in practice rather difficult and in most cases impossible to delineate (Bokiniec, Marciniak 1987; Galinski 1991.

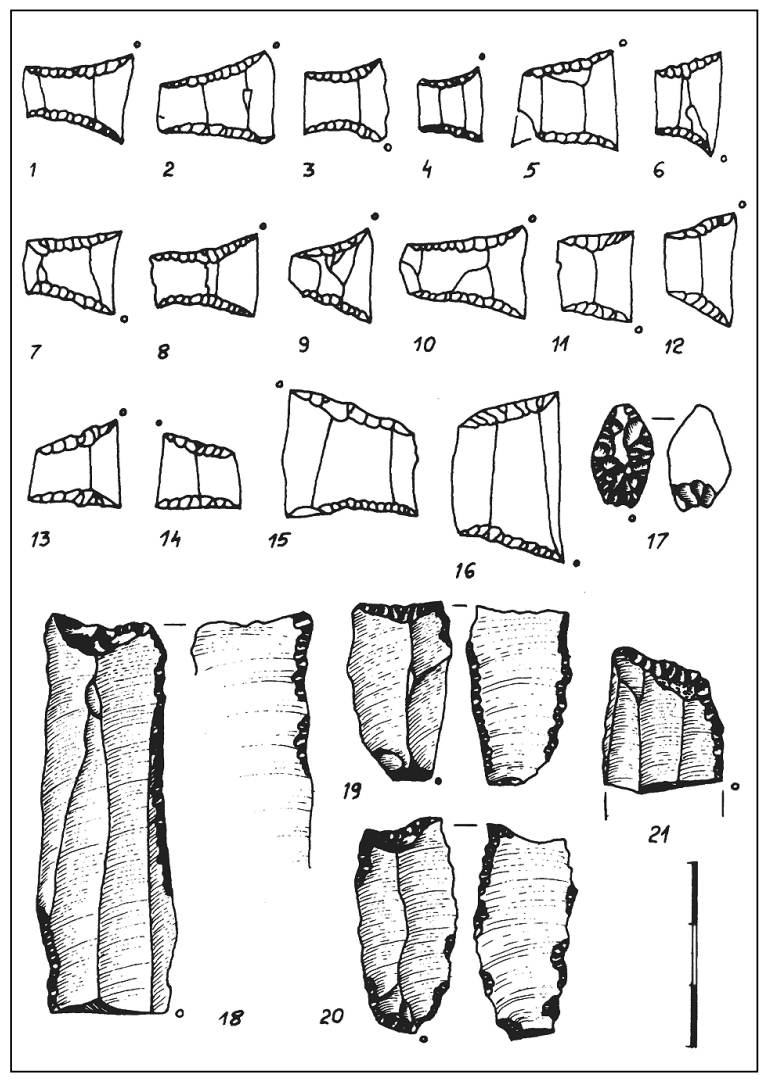

Fig. 5. Selection of flint tools from the site of Tanowo 3, trench II/1999-2002. The standardized industry of late hunter-gatherers (after Galiński 2005.75, Fig. 2). Trapezes: 1-16; arrowhead with surface retouch: 17; blade truncations: 18-21. 
Fig. 6. Division of selected Mesolithic and ParaNeolithic sites, commonly ascribed either to Atlantic or to Subboreal period, according to typological structure of the lithic attributes of late chronology. 1 - Group 1: trapezes and blade truncations occur exclusively within 'geometric' tools; side-scrapers and end-scrapers prevail within remaining tools; lack of micro-burin technique. Bobrowice (Bagniewski 1981; 1982; 2001a); Dąbrowa-Krępnica 5 (Bagniewski 1982); Gorzupia Dolna 2 (Bagniewski 1982; 2001a); Sieraków 4 (Bagniewski 1982; 2001a); Tanowo 3 (Galiński 1992; 2005). 2 - Group 2: only trapezes occur within 'geometric' tools; side-scrapers and end-scrapers prevail within remaining tools; frequent micro-burin tech-

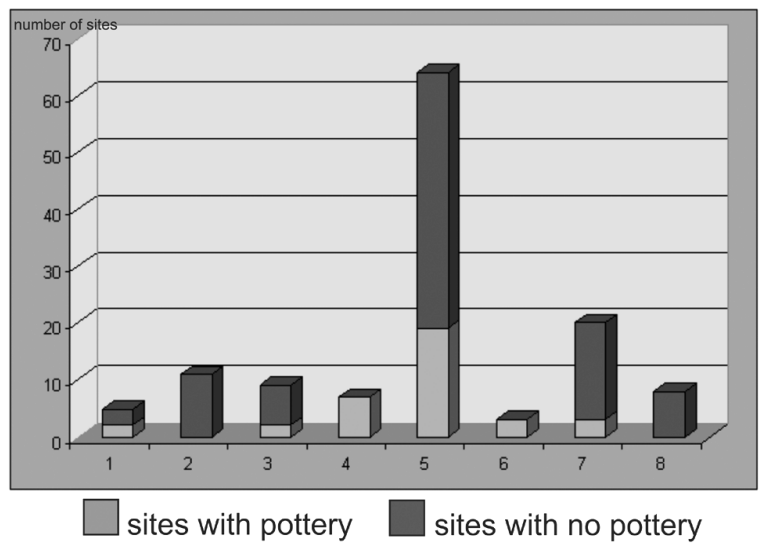
nique. Baraki Stare 13 (Libera, Tymczak 1990); Komornica I (Więckowska 1985); Wieliszew I, sk. II; III, sk. XVI; VIB, wykop XVIIc; 12 (XIV/1960); VIII, wykop IX (Więckowska 1985); Wistka Szlachecka VI) 19660; V/1960; I/1963 (Schild et al. 1975); Poddębe I (Więckowska 1985).

3-Group 3a: c. 30-50\% of trapezes and blade truncations occur within 'geometric tols'; c. 40-60\% of side-scrapers and end-scrapers occur within remaining tools. Dabki 9 (Ilkiewicz 1989); Dobra 53, IV/84 (Galiński 1992; 2002); Gościm 23 (Bagniewski 2001b; 2002); tęczyn 12 (Bagniewski 1999); Męcikat 6 (Bagniewski 1987; 2001a; Kabaciński 2001); Mierzęcin 65 (Bagniewski 2000); Szczecin-Śmierdnica (Galiński 1992); Tanowo 2, I/82 (sk. 2) (Galiński 1992); Wieliszew XIII/1960/62 (Schild et al. 1975). 4 - Group 3b: c. 30-40 \% of trapezes and blade truncations occur within 'geometric tools'; c. 40-50\% of side-scrapers and end-scrapers occur within remaining tools; retouched inserts, points, points with flat and lamellar retouches occur also in tool group. Augustów-Wójtowskie Wtóki (Sulgostowska 1978); Dudka (Gumiński, Fiedorczuk 1988; 1990; Fiedorczuk 1995); Grudziądz-Mniszek (Bokiniec, Marciniak 1987); Sośnia 1 (wyk. II) (Kempisty, Więckowska 1983); Szczepanki (Gumiński 2003b); Woźna Wieś 1; 2 (Kempisty, Sulgostowska 1991).

5 - Group 3c: c. 10-20\% of trapezes and blade truncations occur within 'geometric' tools; c. 30-40\% of side-scrapers and end-scrapers occur within remaining tools. Brodno E (Bagniewski 1982; 1991); Bukówna 5 (Masojć 2004); Buszów (Kendelewicz 2000b); Chrapów 17 (Bagniewski 1999); Chwalim 1 (Kobusiewicz, Kabaciński 1993); Czeladź Wielka I; II (Bagniewski 1976); Dobra 53, I/83; 53, III/83 (Galiński 1992); Dzierżno 3 (Ginter 1972); Glanów 3 (Pazdur et al. 2004; Zając 2001); Grądy Woniecko (Kempisty, Więckowska 1983; Kempisty 1983); Grzepnica 7, sk. E (Galiński 1992); Gwoździec (Libera, Talar 1990); Jastrzębia Góra 4 (Domańska 1983; 1992; Ruta 1997); Korzecznik 6/7 (Olszewski 1987); KoszalinDzierżęcino 7 (Ilkiewicz 1997); Krzekotówek 8 (Bagniewski 1982; 1991); Lubiatów II; III (Bagniewski 1976); tęczyn 13; 22; 23; 25 (Bagniewski 1999); Eykowe 1 (Cyrek 1990); Męcikat 7a; 7 b; 11 (Bagniewski 1987; 1998); Mokracz (Niesiołowska-Śreniowska 1990a; 1998); Mosina 10 (Bagniewski 1995); Mostno 15; 16 (Kendelewicz 2000a); Nowodworce (Nowak 1980); Osjaków (Niesiołowska-Śreniowska 1971; 1973); Pobiel 9; 10 (Bagniewski 1976; 1990); Potasznia 1 (Bagniewski 1976); Prostynia 16 (Bagniewski 1996); Pstraże (Bagniewski 1982); Puszczykowo 21 (Krzyszowski 1997); Siedlisko 16 (Bagniewski 1982); Spalona 12, I, Ia/85 (Masojć 2004); Sutów 1 (Bagniewski 1976); Swornegacie 3; 6 (Bagniewski 1987; 1998); Szczecin-Jezierzyce 19 (Galiński 1992); Świerczów (Bagniewski 1982); Świętoszyn 1; II (Bagniewski 1976; 2001a); Tanowo 3, wyk. VII/91 (Galiński 1992); Trzebicz Mtyn 1; 2 (Bagniewski 2001c; 2001d); Turowiec 1; 3 (Bagniewski 1987; 1998); Wegliny 12 (Bagniewski 1995); Wiechlice I (Bagniewski 1982); Wieliszew XII-XI (Więckowska 1985); Wierzchowo 1; 2 (Bagniewski 1996); Zakrzów 6 (Bronowicki, Masojć 2001); Zbrzyca 2 (Bagniewski 1987); Zwola 2 (Fojud, Kobusiewicz 1978).

6 - Group 4; lack of 'geometric' tools; small number of side-scrapers and end-scrapers; high frequency of flake blanks (c. 50\%); splintered technique. Kuców (Krzyszowski 1995); Stobnica-Trzymorgi (Cyrek et al. 1985; Niesiołowska-Śreniowska 1990b; Wiklak 1990); Wola Raniżowska (Mitura 1994).

7 - Group 5; only single typological attributes of late dating occur; other 'late' elements (pottery, ${ }^{14} \mathrm{C}$ dates) decided on late chronology. Bierzwnik 19 (Bagniewski 1994); Chobienice 8 (Kobusiewicz, Kabaciński 1998); Grzepnica 7, I/84 (Galiński 1992); Gudowo 3 (Bagniewski 1996);Jaglisko 1 (Bagniewski 1994); Jaroszówka-Kolonia 10 (Masojć 2004); Jastrzębnik 5 (Masojć 2004); Kalisz Pomorski 33 (Bagniewski 1996); Lugi E (Bagniewski 1982); Miatka 4 (Bagniewski 2001e); Pianki I, II (Kozłowski 1989); Pietrzyków "g" (Kobusiewicz 1963; 1999); Pomorsko 1 (Kobusiewicz, Kabaciński 1991); Poznań-Starołęka 1 (Kobusiewicz 1961; 1999); Rzeszotary 17 (Masojć 1999; 2004); Smolno Wielkie 1; 2 (Kobusiewicz 1999); Wojnowo 1 (Kobusiewicz 1999); Zamienice 10 (Masojć 1999; 2004); Zbrzyca 5 (Bagniewski 1987).

8 - Group 6; lack of any typological attributes of late dating; other 'late' elements (pottery, 14 C dates) decided on late chronology. Bartków 7 (Bagniewski 1976; 1982); Brodno 3 (Bagniewski 1982); Nur-Kolonia 1 (Kozłowski 1989); Siedlnica 6 (Bagniewski 1979); Stochy Annopolskie (Kozłowski 1989); Świętoszyn III (Bagniewski 1976); Witów 1 (Chmielewska 1978; Cyrek et al. 1985). 


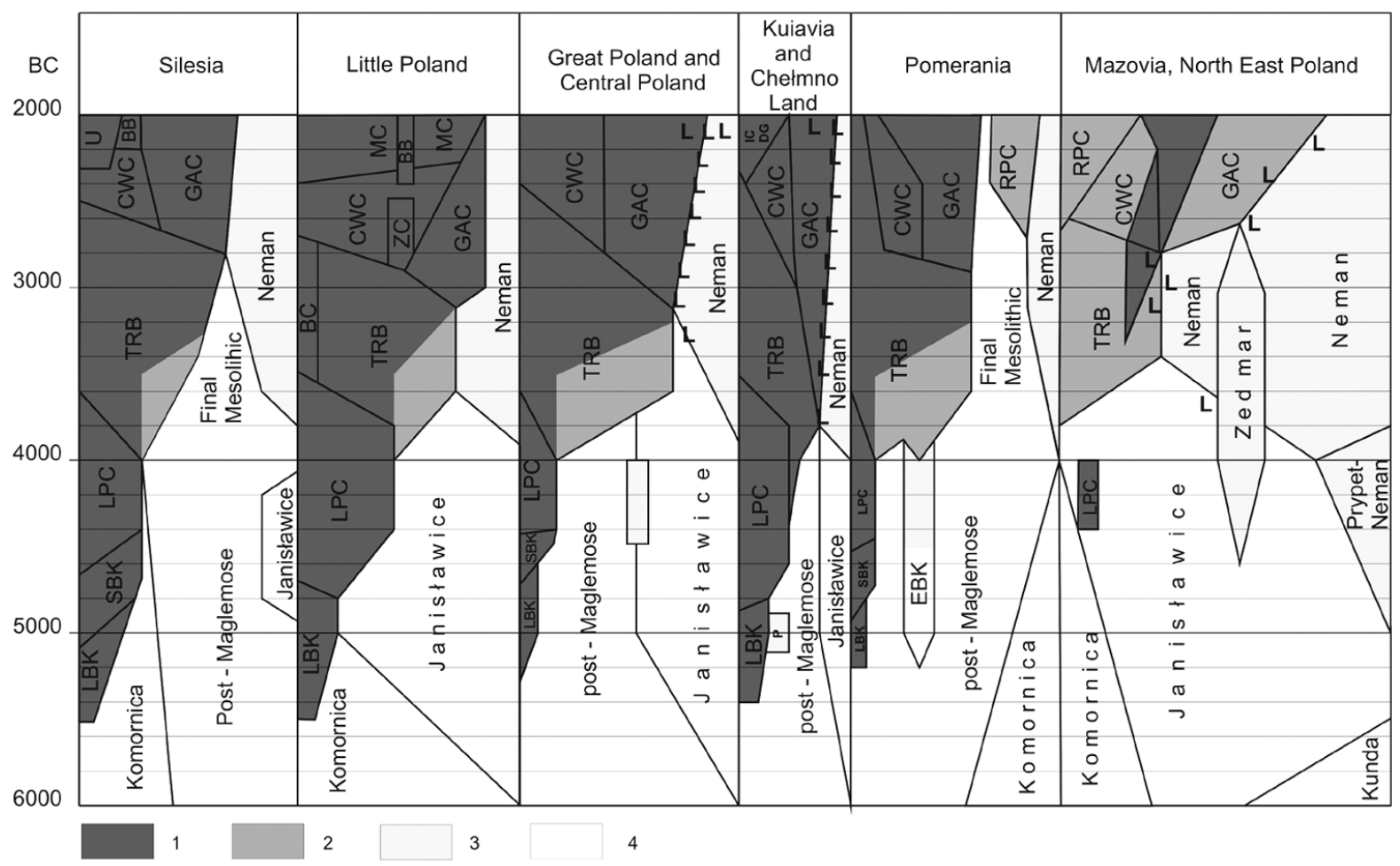

Fig. 7. Archaeological cultures and related main socio-economic formations in Polish territories between 6000 and 2000 BC. 1 - agro-pastoral and pastoral Neolithic, 2 - agro-pastoral Neolithic with significant contribution of hunting and gathering, 3 - pottery-using hunter-gatherers (para-Neolithic), 4 - huntergatherers (Late and Final Mesolithic). LBK - Linear Band Pottery Culture; SBK - Stroke Band Pottery Culture; LPC - Lengyel-Polgar Complex; TRB - Funnel Beaker Culture; GAC - Globular Amphorae Culture; CWC - Corded Ware Culture; U - Únětice Culture; BB - Bell Beakers; BC - Baden Culture; ZC - Ztota Cul ture; MC - Mierzanowice Culture; P - sites of Podgaj 32 type; IC - Iwno Culture; DG - Dobre Group; RPC Rzucewo/Pamariu Culture; $L$ - pottery of Linin type.

23-25; Gumiński 2003b.81-82; Gumiński, Fiedorczuk 1988.140, 143).

Therefore, contrary to the previously quoted allochtonous views, regional variations of the para-Neolithic cultures in East Central Europe do appear to have been a continuation of older indigenous Mesolithic groups, the implementation of pottery being the only cultural tradition adopted from the East. I dare say again that the genetic pool of para-Neolithic populations was basically the same as that of Mesolithic populations. Some specific features of paraNeolithic pottery which were not derived from the East may seem to confirm such a suggestion. Also, settlement and economic data can support this view.

As regards settlement patterns, we can speak of longlasting settlement in at least several regions. The site Dudka in the Mazurian Lakeland may serve here as an example (Gumiński 1998; 2003a; 2005; Guminski, Michniewicz 2003). The remains of succeeding camps, from the Alleröd to mid Subboreal, were detected here. It is symptomatic that a pure hunter-gatherer economy predominated within these groups.
Another representative example of such a pattern is the Chwalim site in western Great Poland (Kobusiewicz, Kabacinski 1993). The so-called upper layer is dated to the late fourth millennium BC. This layer contained pottery of Linin type B (according to Szmyt). But the main point is that a collection of ani$\mathrm{mal}$ bones found in the layer is completely devoid of bones of domesticated animals. And this is rather surprising as the site is located right within the range of Neolithic cultures.

\section{Conclusions}

In my opinion we are entitled to put forward the following conclusions (see also Fig. 7):

(1) The 'history' of hunter-gatherers in East Central Europe was very long and lasted until the Early Bronze Age.

(2) Some Mesolithic hunting-gathering groups changed their material culture, economy and settlement pattern in the fourth millennium $\mathrm{BC}$, i.e. became Neolithic farmers (mainly of the Funnel Beaker Culture). 
(3) Certainly no regression is discernible within the remaining hunter-gatherer populations. Previous patterns seem to have continued, even though the territories settled by farming societies were steadily growing in size.

$(4$ On the other hand, hypotheses about the growing complexity of Late Mesolithic communities, as posed in relation to other territories - regardless of the validity of such hypotheses for the mid-Holocene in Central Europe - are not corroborated by finds from the territory of Poland (no large settlements, permanent burial sites, or signs of settlement stability).

5 Notably, throughout their existence, we observe no increase in importance of agriculture and breeding among these populations. At the same time, an element that formally looked forward to the Neolithic was vessel ceramics.

6 The distinction between the Late/Final Mesolithic and para-Neolithic in East Central Europe is overestimated. What is meant in both cases is hunter-gathe- rer groups, which to a large extent had preserved settlement, economic, social and ideological patterns of the classic Mesolithic. The most significant factor here is the continuation of a very efficient adaptation of settlement and economy to the Holocene, forest environments in the temperate and boreal zones. However, taking into account the status of their lithic industries, relatively far from the classical Mesolithic, the exclusive employment of the term 'paraNeolithic' (both for the 'pure' Late/Final Mesolithic and 'pottery using hunter-gatherers') should be considered.

$(7$ In terms of Availability Model (Zvelebil, RowleyConwy 1984; 1980), we should ascertain that huntergatherer populations remained on the level of availability all the time, i.e. from $c .5500 \mathrm{BC}$. It is difficult to construct the situation that could be referred to as Substitution Phase. Consequently, it seems that transitions to the Consolidation Phase in the period between 5500 and $2300 \mathrm{BC}$ were relatively quick and decisive.

\section{REFERENCES}

ANTANAITIS I. 1999. Concerning the transition to farming in the East Baltic. In M. Budja (ed.), $\sigma^{\text {th }}$ Neolithic Studies. Documenta Praehistorica 26: 89-100.

ARTS N. 1989. Archaeology, environment and the social evolution of later band societies in a lowland area. In C. Bonsall (ed.), The Mesolithic in Europe. Papers Presented at the Third International Symposium. Edinburgh University Press. Edinburgh: 291-312.

BAGNIEWSKI Z. 1976. Uwagi o osadnictwie kultur mezolitycznych w dorzeczu Baryczy. Studia Archeologiczne 7: 3-35.

1979. Społeczności myśliwsko-rybackie w okresie od IX do III tysiaclecia p.n.e. na terenie Polski potudniowo-zachodniej. Ossolineum. Wrocław.

1981. Das Problem der Koexistenz mesolitischer und neolitischer Gesellschaften im Südteil des mitteleuropäischen Flachlandes. Veröffentlichungen des Museums für Ur-und Frühgeschichte Potsdam 14/15: 113119.

1982. Społeczności myśliwsko-rybackie w okresie od IX do III tysiaclecia p.n.e. na terenie Polski potu- dniowo-zachodniej, część II. Studia Archeologiczne 11: 41-116.

1987. Mezolityczne spoteczności myśliwsko-rybackie potudniowej cześci Pojezierza Kaszubskiego. Studia Archeologiczne 17.

1990. Obozowisko mezolityczne z doliny Baryczy. Pobiel 10, woj. leszczyńskie. Studia Archeologiczne 19.

1991. Niektóre problemy mezolitu środkowego Nadodrza. Studia Archeologiczne 20: 3-22.

1994. Wczesnoholoceńskie osadnictwo Pojezierza Dobiegniewskiego. Ślaskie Sprawozdania Archeologiczne 35: $179-205$.

1995. 0 obecności stanowisk kultury Duvensee na terenie Polski zachodniej. Studia Archeologiczne 26: 123-146.

1996. Mezolit Pojezierza i Równiny Drawskiej. Studia Archeologiczne 28.

1998. Later Mesolithic settlement in Central and Eastern Pomerania. In M. Zvelebil, L. Domańska, R. Den- 
nell (eds.), Harvesting the Sea, Farming the Forest: The Emergence of Neolithic Societies in the Baltic Region. Sheffield Academic Press. Sheffield: 111-119.

1999. Mezolityczna enklawa osadnicza na Polanie Lęzyńskiej (Pojezierze Dobiegniewskie). Uniwersytet Wrocławski, Katedra Archeologii. Wrocław.

2000. Pozostałości obozowiska mezolitycznego na stanowisku Mierzęcin 65 (Pojezierze Dobiegniewskie). Śląkie Sprawozdania Archeologiczne 42: 61-74.

2001a. Wczesnoholoceńskie ugrupowania mezolityczne na terenie zachodniej Polski. Fontes Archaeologici Posnanienses 39: 75-94.

2001b. Z badań poszukiwawczych w rejonie Gościmia (Kotlina Gorzowska). Ślaskie Sprawozdanie Archeologiczne 43: 499-502.

2001c. Wielofazowe obozowisko Trzebicz Młyn stan. 2 (Kotlina Gorzowska). Ślaskie Sprawozdania Archeologiczne 43: 35-48.

2001d. Obozowisko maglemoskie Trzebicz Młyn stan. 1 (Kotlina Gorzowska). Ślaskie Sprawozdania Archeologiczne 43: 49-62.

2001e. 0 paleolicie schyłkowym i mezolicie Pomorza. In B. Ginter et al. (eds.), Problemy epoki kamienia na obszarze Starego Świata. Księa jubileuszowa dedykowana Profesorowi Januszowi K. Kozłowskiemu w czterdziestolecie pracy naukowej na Uniwersytecie Jagiellońskim. Instytut Archeologii Uniwersytetu Jagiellońskiego. Kraków: 203-228.

2002. Wyniki dalszych badań obozowiska mezolitycznego Gościm 23 (Kotlina Gorzowska). Śląskie Sprawozdania Archeologiczne 44: 111-124.

BOKINIEC A. Z., MARCINIAK M. 1987. Wstępne wyniki badań na wielokulturowym stanowisku Grudziądz-Mniszek 3, woj. toruńskie. In T. Wiślański (ed.), Neolit i początki epoki brazu na Ziemi Chetminskiej. Materiaty z międzynarodowego sympozjum, Toruń, 11-13 XI 1986. Biuro Badań i Dokumentacji Zabytków w Toruniu, Muzeum Okręgowe w Toruniu, Instytut Archeologii i Etnografii Uniwersytetu im. Mikołaja Kopernika, Toruń: 223-248.

BRONOWICKI J., MASOJĆ M. 2001. Krzemienica mezolityczna oraz problematyka krzemieniarstwa epoki kamienia i okresu halsztackiego stanowiska Zakrzów 6, pow. Krapkowice. Ślaskie Sprawozdania Archeologiczne 43: 77-94.

ČARNIAUSKI M. 2004. Niealit Biełarusi: prabliemy pieryiadyzacyi i chranałogii. In A. Kośko, A. Kalečyc (eds.), Wspólnota dziedzictwa kulturowego ziem Białorusi $i$
Polski. Ośrodek Ochrony Dziedzictwa Archeologicznego, Warszawa: 34-46.

CHMIELEWSKA M. 1978. Późny paleolit Pradoliny Warszawsko-Berlińskiej. Ossolineum. Wrocław.

CUPILLARD C., PERRENOUD-CUPILLARD N. 2003. The Mesolithic of the Swiss and French Jura and its margins: 10,150-6000 BP. In L. Larsson, H. Kindgren, K. Knutson, D. Loeffler, A. Åkerlund (eds.), Mesolithic on the Move. Papers Presented at the Sixth International Conference on the Mesolithic in Europe, Stockholm 2000. Oxbow. 0xford: 82-95.

CYREK K. 1990. Ausgrabungen auf einer mesolitischen und neolitischen Fundstelle bei Łykowe in Mittelpolen. In Vermersch P., Van Peer M. P. (eds.), Contributions to the Mesolithic in Europe. Papers Presented at the Fourth International Symposium "The Mesolithic in Europe", Leuven 1990. Leuven University Press, Leuven: 281-293.

CYREK K., GRYGIEL R., NOWAK K. 1985. Mezolit ceramiczny w środkowej i północno-wschodniej Polsce i jego związki z neolitycznymi kulturami niżowymi. Prace $i \mathrm{Ma}$ teriaty Muzeum Archeologicznego i Etnograficznego $w$ Lodzi 29 (1982): 5-70.

CZEBRESZUK, J. 2004. Z zachodu na wschód i ze wschodu na zachód: „kultury pucharowe” i ugrupowania leśnowschodnioeuropejskie na przełomie epok neolitu i brazu. In A. Kośko, A. Kaleczyc (eds.), Wspólnota dziedzictwa kulturowego ziem Białorusi i Polski. Ośrodek Ochrony Dziedzictwa Archeologicznego, Warszawa: 119-136.

CZERNIAK L. 1994. Wczesny i środkowy okres neolitu na Kujawach 5400-3650 p.n.e. Instytut Archeologii i Etnologii Polskiej Akademii Nauk. Poznań.

DE ROEVER J. P. 2004. Swifterband-aardewerk. Eine analyse van de neolitische nederzettingen bij Swifterbant, 5 e millennium voor Christus. Barkhuis. Groningen.

DOLUKHANOV P., SHUKUROV A., GRONENBORN D., SOKOLOFF D., TIMOFEEV V., ZAITSEVA G. 2005. The chronology of Neolithic dispersal in Central and Eastern Europe. Journal of Archaeological Science 32: 1441-1458.

DOMAŃSKA L. 1983. Wybrane zagadnienia krzemieniarstwa strefy nadmorskiej w epoce kamienia. In T. Malinowski (ed.), Problemy epoki kamienia na Pomorzu. Wyższa Szkoła Pedagogiczna w Słupsku, Słupsk: 217-228.

1992. Udział komponentu maglemoskiego w rozwoju kulturowym późnomezolitycznych społeczeństw Pomorza w świetle badań na stanowisku Jastrzębia Góra 4, woj. Gdańsk. Folia Archaeologica 16: 61-69. 
FIEDORCZUK J. 1995. Mesolithic finds at Dudka 1, Great Masurian Lakeland, and their chronological-taxonomic relations. Przeglad Archeologiczny 43: 47-59.

FISCHER A. 1989. Hunting with flint-tipped arrows: results and experiences from practical experiments. In C. Bonsall (ed.), The Mesolithic in Europe. Papers Presented at the Third International Symposium, Edinburgh 1985. Edinburgh University Press, Edinburgh: 29-39.

FOJUD R., KOBUSIEWICZ M. 1978. Osadnictwo z epoki kamienia w Zwoli, woj. poznańskie. Wiadomości Archeologiczne 43: 18-31.

GALIŃSKI T. 1991. Uwagi na temat mezolitu ceramicznego i neolitu strefy leśnej na Niżu polskim. Archeologia Polski 36: 5-72.

1992. Obozowisko mezolityczne i protoneolityczne na stanowisku w Tanowie badane w latach 1989-1991. Materiaty Zachodniopomorskie 38: 53-122.

1994. Przemysł krzemienny zespołów końcowomezolitycznych i protoneolitycznych w Europie Zachodniej i na Pomorzu. Materiaty Zachodniopomorskie 40: 7-74.

2002. Społeczeństwa mezolityczne: osadnictwo, gospodarka, kultura ludów towieckich w VIII-IV tysiącleciu p.n.e. na terenie Europy. Muzeum Narodowe w Szczecinie, Szczecin.

2005. Nowe materiały tzw. fazy wczesnopucharowej osadnictwa protoneolitycznego na Pomorzu. Folia Praehistorica Posnaniensia 13/14: 71-90.

GINTER B. 1972. Dwa stanowiska mezolityczne z miejscowości Dzierżno, pow. Gliwice. Rocznik Muzeum Górnośląskiego w Bytomiu, Archeologia 10: 7-76.

GRONENBORN D. 1999. A variation on a basic theme: the transition to farming in southern Central Europe.Journal of World Prehistory 13: 123-210.

2003. Migration, acculturation and culture change in western temperate Eurasia, 6500-5000 cal BC. In M. Budja (ed.), 10th Neolithic Studies. Documenta Praehistorica 30: 79-91.

GUMIŃSKI W. 1998. The peat-bog site Dudka, Masurian Lakeland: an example of conservative economy. In M. Zvelebil, L. Domańska, R. Dennell (eds.), Harvesting the Sea, Farming the Forest: The Emergence of Neolithic Societies in the Baltic Region. Sheffield Academic Press, Sheffield: 103-109.

1999. Środowisko przyrodnicze a tryb gospodarki i osadnictwa w mezolicie i paraneolicie na stanowisku Dudka w Krainie Wielkich Jezior Mazurskich. Archeologia Polski 44: 31-74.
2001. Kultura Zedmar. Na rubieży neolitu "zachodniego". In J. Czebreszuk, M. Kryvalcevič, P. Makarewicz (eds.), Od neolityzacji do poczatków epoki brazu. Przemiany kulturowe $w$ między rzeczu Odry $i$ Dniepru między VI i II tys. przed Chr. Wydawnictwo Poznańskie, Poznań: 133-152.

2003a. Big game and sparse forest - relations between mammals species and the surrounding environment at the prehistoric fishing campsite of Dudka in Masuria, NE-Poland. Archaeozoologia 21: 59-72.

2003b. Szczepanki 8. Nowe stanowisko torfowe kultury Zedmar na Mazurach. Światowit 46 (New Series 5, fasc. B): 53-104.

2005. Bird for dinner. Stone Age hunters of Dudka and Szczepanki, Masurian Lakeland, NE-Poland. Acta Archaeologica 76: 111-148.

GUMIŃSKI W., FIEDORCZUK J. 1988. Badania w Dudce, woj. suwalskie, a niektóre problemy epoki kamienia $\mathrm{W}$ Polsce północno-wschodniej. Archeologia Polski 33: 113150.

1990. Dudka 1. A Stone Age peat-bog site in NorthEastern Poland. Acta Archaeologica 60: 51-70.

GUMIŃSKI W., MICHNIEWICZ M. 2003. Forest and mobility. A case from the fishing camp site Dudka, Masuria, North-Eastern Poland. In L. Larsson, H. Kindgren, K. Knutson, D. Loeffler, A. Åkerlund (eds.), Mesolithic on the Move. Papers Presented at the Sixth International Conference on the Mesolithic in Europe, Stockholm 2000. Oxbow, Oxford: 119-127.

ILKIEWICZ J. 1989. From studies on cultures of the $4^{\text {th }}$ millennium BC in the central part of the Polish coastal area. Przeglad Archeologiczny 36: 17-56.

1997. From studies on Ertebølle type cultures in the Koszalinian coastal area (Dąbki 9, Koszalin-Dzierżęcino 7). In D. Król (ed.), The Built Environment of Coast Areas during the Stone Age. Regional Centre for Studies and Preservation of Built Environment in Gdańsk, Gdańsk: 50-65.

JANIK L. 1998. The appearance of food producing societies in the Southeastern Baltic Sea region. In M. Zvelebil, L. Domańska, R. Dennell (eds.), Harvesting the Sea, Farming the Forest: The Emergence of Neolithic Societies in the Baltic Region. Sheffield Academic Press, Sheffield: 237-243.

JOCHIM M. 1998. A Hunter-Gatherer Landscape. Southwest Germany in the Late Palaeolithic and Mesolithic. Plenum Press, New York-London. 
JÓZWIAK B. 2003. Społeczności subneolitu wschodnioeuropejskiego na Niżu Polskim $w$ międzyrzeczu Odry $i$ Wisty. Uniwersytet im. Adama Mickiewicza, Poznań.

KABACIŃSKI J. 1992. O homogeniczności stanowisk archeologicznych. Uwagi do artykułu T. Galińskiego "Zespoły typu Tanowo. Zachodniopomorski ekwiwalent ugrupowania Ertebølle-Ellerbek-Lietzow". Przeglad Archeologiczny 40: $105-112$.

2001. The Mesolithic-Neolithic transition in the southern Baltic Coastlands. Fontes Archaeologici Posnanienses 39: 129-162.

KALEČYC, A. 2001. Perechod da vytvorčaj gaspadarki na terytoryi Belarusi (šlagi i čas). In J. Czebreszuk, M. Kryvalcevič, P. Makarowicz (eds.), Od neolityzacji do poczatków epoki brazu. Przemiany kulturowe $w$ międzyrzeczu Odry i Dniepru między VI i II tys. przed Chr. Wydawnictwo Poznańskie, Poznań: 29-42.

KANWISZER A., TRZECIAK P. 1991. Łódź radiocarbon dates III. Radiocarbon 33: 115-130.

KEMPISTY E. 1972. Materiały tzw. kultury ceramiki grzebykowo-dołkowej z terenu Mazowsza i Podlasia. Wiadomości Archeologiczne 37: 411-483.

1973. Kultura ceramiki grzebykowo-dołkowej na Mazowszu i Podlasiu. Wiadomości Archeologiczne 38: 3-76.

1982. Reviev: T. Wiślański, Krąg ludów subneolitycznych w Polsce, [w:] Prehistoria Ziem Polskich, t. 2. Neolit, Wrocław-Warszawa-Kraków-Gdańsk 1979. Archeologia Polski 26: 436-444.

1983. Neolityczne kultury strefy leśnej w północnej Polsce. In T. Malinowski (ed.), Problemy epoki kamienia na Pomorzu. Wyższa Szkoła Pedagogiczna w Słupsku, Słupsk: 75-99.

KEMPISTY E., SULGOSTOWSKA Z. 1991. Osadnictwo paleolityczne, mezolityczne $i$ paraneolityczne $w$ rejonie Woźnej Wsi, woj. łomżyńskie. Instytut Historii Kultury Materialnej Polskiej Akademii Nauk, Warszawa.

KEMPISTY E., WIĘCKOWSKA H. 1983. Osadnictwo z epoki kamienia $i$ wczesnej epoki brazu na stanowisku $1 \mathrm{w}$ Sośni, woj. tomżyńskie. Ossolineum, Wrocław.

KENDELEWICZ T. 2000a. Wyniki badań stanowisk mezolitycznych Mostno 15 i Mostno 16, pow. Myślibórz. Śląskie Sprawozdania Archeologiczne 42: 75-90.

2000b. Badania w 1999 roku w Buszowie stan. 1, pow. Gorzów. Śląskie Sprawozdania Archeologiczne 42: 91-108.
KIND J. 1997. Die mesolitische Freiland-Stratigraphie von Rotenburg „Siebenlinden 3“. Archäologisches Korrespondenzblatt 27: 13-32.

KOBUSIEWICZ M. 1961. Stanowisko z końca paleolitu i poczatków mezolitu z Poznania-Starołęki. Fontes Archaeologici Posnanienses 12: 1-23.

1963. Krzemienica przemysłu tardenuaskiego z Pietrzykowa, pow. Września. Fontes Archaeologici Posnanienses 14: 1-13.

1999. Ludy towiecko-zbierackie pótnocno-zachodniej Polski. Poznańskie Towarzystwo Przyjaciół Nauk, Poznań.

2001. Paraneolithic - the middle Holocene traditionalists. In B. Ginter et al. (eds.), Problemy epoki kamienia na obszarze Starego Świata. Księga jubileuszowa dedykowana Profesorowi Januszowi K. Kozłowskiemu w czterdziestolecie pracy naukowej na Uniwersytecie Jagiellońskim. Instytut Archeologii Uniwersytetu Jagiellońskiego, Kraków: 241-248.

KOBUSIEWICZ M., KABACIŃSKI J. 1991. Late Mesolithic dwelling object in Pomorsko (Western Poland). Przeglad Archeologiczny 38: 5-16.

1993. Chwalim. Subboreal Hunter-Gatherers of the Polish Plain. Institute of Archaeology and Ethnology, Polish Academy of Sciences, Poznań.

1998. Some aspects of the Mesolithic-Neolithic transition in the western part of the Polish Lowlands. In M. Zvelebil, L. Domańska, R. Dennell (eds.), Harvesting the Sea, Farming the Forest: The Emergence of Neolithic Societies in the Baltic Region. Sheffield Academic Press, Sheffield: 95-102.

KOŚKO, A., M. SZMYT. 2004. Problem wschodniej rubieży kultur neolitycznych Niżu środkowoeuropejskiego: VI - III tys. BC. In A. Kosko, A. Kalečyc (eds.), Wspólnota dziedzictwa kulturowego ziem Białorusi i Polski. Ośrodek Ochrony Dziedzictwa Archeologicznego, Warszawa: 80-98.

KOZŁOWSKI S. K. 1987. The Pre-neolithic base of the Early Neolithic stone in Europe. In J. K. Kozłowski, S. K. Kozłowski (eds.), Chipped Stone Industries of the Early Farming Cultures in Europe. Archaeologia Interregionalis 9. Wydawnictwa Uniwersytetu Warszawskiego, Warszawa: 9-18.

1989. Mesolithic in Poland. A New Approach. Wydawnictwa Uniwersytetu Warszawskiego, Warszawa.

2001. Eco-cultural/stylistic zonation of the Mesolithic/ Epipalaeolithic in Central Europe. In R. Kertész, J. Makkay (eds.), From the Mesolithic to the Neolithic. 
Proceedings of the International Archaeological Conference held in the Damjanich Museum of Szolnok, September 22-27, 1996. Archaeolingua, Budapest: 261-282.

KOZŁOWSKI J. K., KOZŁOWSKI S. K. 1986. Foragers of Central Europe and their acculturation. In M. Zvelebil (ed.), Hunters in Transition. Mesolithic Societies of Temperate Eurasia and Their Transition to Farming. Cambridge University Press, Cambridge: 95-108.

KRZYSZOWSKI A. 1995. Osadnictwo neolityczne na stanowisku 1 w Kucowie, gm. Kleszczów, woj. Piotrków Trybunalski. Prace $i$ Materiaty Muzeum Archeologicznego $i$ Etnograficznego w todzi 37-38: 25-63.

1997. Obozowisko mezolityczne $\mathrm{z}$ pierwszej połowy okresu atlantyckiego w Puszczykowie w województwie poznańskim. Fontes Archaeologici Posnanienses 38: 13-35.

KUKAWKA S. 1997. Na rubieży środkowoeuropejskiego świata rolniczego. Społeczności Ziemi Chetmińskiej w IV tysiacleciu p.n.e. Uniwersytet Mikołaja Kopernika, Toruń.

LARSSON L. 1990. The Mesolithic of Southern Scandinavia. Journal of World Prehistory 4: 257-299.

LIBERA J., TALAR A. 1990. Osadnictwo kultury janisławickiej w Gwoźdźcu, stan. 9, gm. Bojanów, woj. Tarnobrzeg, w świetle badań 1966-1967. Sprawozdania Archeologiczne 42: 9-68.

LIBERA J., TYMCZAK D. 1990. Późnomezolityczne stanowisko 13 w Barakach Starych, gm. Zaklików, woj. Tarnobrzeg. Sprawozdania Archeologiczne 42: 69-94.

LOUVE-KOOIJMANS L. P. 2003. The Hardinxveld sites in the Rhine/Mouse Delta, the Netherlands, 5500-4500 cal BC. In L. Larsson, H. Kindgren, K. Knutson, D. Loeffler, A. Åkerlund (eds.), Mesolithic on the Move. Papers Presented at the Sixth International Conference on the Mesolithic in Europe, Stockholm 2000. Oxbow, Oxford: 608-624.

MASOJĆ M. 1999. Późnomezolityczna krzemienica z Zamienic 10, gm. Chojnów, Śląskie Sprawozdania Archeologiczne 41: 123-132.

2004. The Mesolithic in Lower Silesia in the Light of Settlement Phenomena of the Kaczawa River Basin. Wydawnictwo Uniwersytetu Wrocławskiego. Wrocław.

MITURA P. 1994. Obozowisko ludności subneolitycznej na stanowisku 22 w Woli Raniżowskiej-Stecach, gm. Raniżów, woj. Rzeszów. Sprawozdania Archeologiczne 46: 13-30.
NIESIOŁOWSKA-ŚRENIOWSKA E. 1971. Sprawozdanie Z dotychczasowych badań na stanowisku 3 w Osjakowie, pow. Wieluń. Prace $i$ Materiaty Muzeum Archeologicznego i Etnograficznego $w$ Lodzi 18: 77-92.

1973. The problem of Mesolithic traditions in the Neolithic cultures in Poland. In S. K. Kozłowski (ed.), The Mesolithic in Europe. Warsaw University Press, Warszawa: 441-454.

1990a. Mokracz - a Mesolithic site in Central Poland: organisation and subsistence. In Vermersch P., Van Peer M. P. (eds.), Contributions to the Mesolithic in Europe. Papers Presented at the Fourth International Symposium "The Mesolithic in Europe", Leuven 1990. Leuven University Press, Leuven: 305-316.

1990b. Zespół krzemienny tzw. kultury ceramiki grzebykowo-dołkowej ze stanowiska 2 w Stobnicy Trzymorgach, województwo piotrkowskie w kontekście materiałów z epoki kamienia. Prace $i$ Materiaty Muzeum Archeologicznego $i$ Etnograficznego $w$ Łodzi 34 (1987): 47-78.

1998. Warunki egzystencji i organizacja przestrzenna obozowiska późnomezolitycznego w Mokraczu, w Polsce środkowej. Prace i Materiaty Muzeum Archeologicznego i Etnograficznego w Lodzi 39(1993-1996): 65-128.

NOWAK K. 1980. Zur Problematik des Mesolithikums in Nordostpolen. Veröffentlichungen des Museums für Urund Frühgeschichte Potsdam 14/15: 355-371.

NOWAK M. 2001. The second phase of Neolithization in east-central Europe. Antiquity 75: 582-592.

OLSZEWSKI P. A. 1987. Osadnictwo epimezolityczne $w$ Korzeczniku, woj. konińskie, stanowisko 6/7. Uniwersytet im. Adama Mickiewicza, Bydgoskie Towarzystwo Naukowe. Inowrocław.

PAZDUR A., FOGTMAN M., MICHCZYŃSKI A., PAWLYTA J., ZAJĄC M. 2004. ${ }^{14} \mathrm{C}$ chronology of Mesolithic sites from Poland and the background of environmental changes. Radiocarbon 46: 809-826.

PAZDUR M. 1991. Radiocarbon chronology of the site Dąbki. Przegląd Archeologiczny 38: 33-34.

PAZDUR M. F., AWSIUK R., GOSLAR T., PAZDUR A., WALANUS A., ZASTAWNY A. 1994. Gliwice radiocarbon dates XI. Radiocarbon 36: 257-279.

RAEMAEKERS D. C. M. 1999. The Articulation of a 'New Neolithic'. The Meaning of the Swifterbant Culture for the Process of Neolithisation in the Western Part of North European Plain (4900-3400 BC). Leiden University. Leiden. 
RIMANTIENE R. 1992. The Neolithic of the Eastern Baltic. Journal of World Prehistory 6: 97-143.

1994. Die Steinzeit in Litauen. Bericht der RömischGermanischen Kommission 75: 23-147.

1998. The first Narva culture farmers in Lithuania. In M. Zvelebil, L. Domańska, R. Dennell (eds.), Harvesting the Sea, Farming the Forest: The Emergence of Neolithic Societies in the Baltic Region. Sheffield Academic Press, Sheffield: 213-218.

RUTA S. 1997. Materiały krzemienne z późnomezolitycznego stanowiska Jastrzębia Góra 4, województwo gdańskie. Folia Archaeologica 21: 7-30.

SCHILD R. 1989. The formation of homogenous occupation units ('Kshemenitsas') in open-air sandy sites and its significance for the interpretation of Mesolithic flint assemblages. In C. Bonsall (ed.), The Mesolithic in Europe. Papers Presented at the Third International Symposium. Edinburgh 1985. Edinburgh University Press, Edinburgh: 89-98.

1998. The perils of dating open-air sandy sites of the North European Plain. In M. Zvelebil, L. Domańska, R. Dennell (eds.), Harvesting the Sea, Farming the Forest: The Emergence of Neolithic Societies in the Baltic Region. Sheffield Academic Press, Sheffield: 71-76.

SCHILD R., KRÓLIK H., MARCZAK M. 1975. Późny mezolit. Próba wieloaspektowej analizy otwartych stanowisk piaskowych. Ossolineum. Wrocław.

SULGOSTOWSKA Z. 1978. Augustów - Wójtowskie Włóki, woj. suwalskie. Osada paleolityczna i neolityczna. Wiadomości Archeologiczne 43: 173-211.

1998. Continuity, change and transition: the case of North-Eastern Poland during the Stone Age. In M. Zvelebil, L. Domańska, R. Dennell (eds.), Harvesting the Sea, Framing the Forest: The Emergence of Neolithic Societies in the Baltic Region. Sheffield Academic Press, Sheffield: 87-94.
TAUTE W. 1974. Neue Forschungen zur Chronologie von Spätpaläolithikum und Mesolithikum in Süddeutschland. Archäologische Informationen 2-3: 59-66.

TIMOFEEV V. I. 1998. The beginning of the Neolithic in the Eastern Baltic. In M. Zvelebil, L. Domańska, R. Dennell (eds.), Harvesting the Sea, Farming the Forest: The Emergence of Neolithic Societies in the Baltic Region. Sheffield Academic Press, Sheffield: 225-236.

WĄS M. 2005. Technologia krzemieniarstwa kultury janisławickiej. Instytut Archeologii Uniwersytetu Łódzkiego. Łódź.

WIĘCKOWSKA H. 1985. Osadnictwo późnopaleolityczne i mezolityczne nad dolna Narwia. Ossolineum. Wrocław.

WIKLAK H. 1990. Odkrycia stobnickie w świetle znalezisk kultury ceramiki grzebykowo-dołkowej w Polsce środkowej. Prace i Materiaty Muzeum Archeologicznego i Etnograficznego w Lodzi 34 (1987): 37-46.

WERBART B. 1998. Subneolithic: what is it? - 'Subneolithic' societies and the conservative economies of the Circum-Baltic region. In M. Zvelebil, L. Domańska, R. Dennell (eds.), Harvesting the Sea, Farming the Forest: The Emergence of Neolithic Societies in the Baltic Region. Sheffield Academic Press, Sheffield: 37-44.

ZAJAC M. 2001. Zabytki mezolityczne w zbiorach Muzeum Archeologicznego w Krakowie i ich znaczenie dla poznania mezolitu strefy wyżynnej w Polsce. Materiaty Archeologiczne 32: 19-38.

ZVELEBIL M., ROWLEY-CONWY P. 1984.Transition to farming in Northern Europe: a hunter-gatherer perspective. Norwegian Archaeological Review 17: 104-128.

1986. Foragers and farmers in Atlantic Europe. In M. Zvelebil (ed.), Hunters in Transition. Mesolithic Societies of Temperate Eurasia and Their Transition to Farming. Cambridge University Press, Cambridge: 6793. 